\title{
JAH Forum
}

\section{SLAVERY AND THE ATLANTIC WORLD}

The following two contributions constitute this issue's JAH Forum. The aim of this format is to spark wide-ranging discussions within the journal and to encourage debate with our colleagues outside of African history on significant trends and cutting-edge developments in dynamic subfields of African history. Each Forum consists of two or more essays on a topic of broad interest within African history and beyond. When inviting contributions, the $J A H$ editors ask authors to discuss the proposed topic from their own unique perspectives while providing some assessment of existing scholarship-both historical and interdisciplinary - and some suggestion of where future studies might or should be heading. For this JAH Forum on Slavery and the Atlantic World, we asked Lisa Lindsay and James Sweet to offer their thoughts on the most influential paradigms and approaches that have shaped the history of slavery in the Atlantic world during the last two decades, and to assess the extent to which there has been increased interaction between scholars focusing on slavery in the Americas and those studying African history. We hope you will find the resulting reflections stimulating and provocative. 